\title{
Tingkah Laku Ekonomi-Politik dalam Hegemoni Agama dan Budaya
}

\author{
Mariatul Qibtiyah \\ Fakultas Ilmu Sosial dan Ilmu Politik Universitas Islam Negeri Raden Fatah Palembang \\ Email: tya.mariatulqibtiyah@gmail.com
}

\begin{abstract}
Economic development is not only done by the economy itself, but also can be intervened by others such as religion and culture. Every society has diverse traditions and has diverse religious patterns that cause differences in behavior, especially economic behavior. This article will describe the relationship between religious ethics and economic behavior of people from different cultures, namely Protestant ethics in the West, Confucius in China, and Islam in Indonesia with using library research. Based on this, the religious socio-cultural background, greatly influences the economic behavior of the community so that it impacts on the development of the nation's economy.
\end{abstract}

Keywords: ethics, religion, culture, economy

\begin{abstract}
Abstrak
Perkembangan perekonomian suatu bangsa tidak hanya dipengaruhi oleh unsur ekonomi semata, namun juga dapat diintervensi oleh unsur-unsur lain seperti agama dan budaya. Setiap masyarakat memiliki tradisi yang beraneka ragam dan memiliki pola keagamaan yang bervariasi sehingga hal ini menyebabkan terjadinya perbedaan tingkah laku, khususnya tingkah laku ekonomi. Artikel ini akan menguraikan hubungan antara etika keagamaan dengan tingkah laku ekonomi masyarakat yang berbeda budaya, yaitu etika Protestan di Barat, Konfusius di China, dan Islam di Indonesia dengan menggunakan metode studi pustaka. Berdasarkan hal tersebut, latar belakang sosial budaya keagamaan, sangat mempengaruhi tingkah laku ekonomi masyarakat sehingga berdampak pada perkembangan ekonomi suatu bangsa.
\end{abstract}

Kata kunci : etika, agama, budaya, ekonomi

\section{PENDAHULUAN}

Salah satu segi dari proses perkembangan perekonomian suatu bangsa atau masyarakat atau golongan mungkin dapat dilihat melalui pengaruh unsur-unsur non-ekonomi yang ada terhadap tingkah laku ekonomi bangsa, masyarakat, atau golongan tersebut. Salah satu dari unsur-unsur non- 
ekonomis itu adalah "agama". Dalam hubungan ini persoalannya mungkin dapat dimulai dengan sebuah pertanyaan seperti: Apakah mungkin agama mempunyai pengaruh langsung terhadap tingkah laku ekonomi pemeluk-pemeluknya? Jawabannya mungkin "ya", dan mungkin pula "tidak". Kalau "ya" maka ia mempunyai dua arti, yaitu (1) pengaruh agama mungkin merupakan penghalang atau penghambat terhadap proses perkembangan ekonomi; (2) sebaliknya mungkin pula merupakan perangsang atau pendorong dari proses tersebut. Kalau "tidak" itu berarti bahwa kehadiran atau ketidakhadiran agama tidak mempunyai pengaruh apa-apa terhadap tingkah laku manusia dalam proses perkembangan ekonominya (Alfian, 1986).

Agama dan nilai-nilai tradisional mendapat serangan dari para teoritisi modernisasi-klasik. Kedua hal itu dituding sebagai faktor yang tidak mendukung industrialisasi karena sifatnya yang tidak rasional. Tetapi kenyataannya, serangan tersebut tidak sepenuhnya terbukti (Chalid, 2005, 10). Di dalam masyarakat tradisional, pranata agama berfungsi untuk mendorong manusia terlibat dalam peran-peran dan tingkah laku ekonomi karena agama mengurangi rasa cemas dan rasa takut. Studi yang dilakukan Malinowski di kalangan masyarakat Trobriand, misalnya, menemukan bahwa masyarakat tersebut selalu mengadakan upacara-upacara ritual tertentu sebelum melaksanakan kegiatan mencari ikan di laut. Di dalam masyarakat yang makin modern, peran pranata agama di dalam kegiatan ekonomi relatif berkurang. Pranata ekonomi yang umumnya menekankan pentingnya rasionalitas dan sekulerisme acap menyebabkan ia harus bersilang kepentingan dengan pranata agama yang menekankan kepercayaan kepada hal-hal supernatural. Di dalam masyarakat modern, keberadaan pranata agama relatif terpisah dari pranata ekonomi (Narwoko \& Suyanto, 2011).

Karakteristik pembangunan ekonomi suatu negara juga amat dipengaruhi oleh karakter budaya yang berkembang. Dalam tatanan budaya, terdapat banyak komponen pembentuk sebuah budaya. Dalam sebuah budaya, terkandung unsur nilai-nilai informal, dan norma-norma yang membentuk karakter dan pola perilaku ekonomi manusia. Pengaruh budaya dalam perilaku ekonomi terlihat pada pengaruh budaya terhadap aktivitas produksi, pola konsumsi dan produktivitas, melalui kemampuan individu untuk menciptakan dan mengendalikan sebuah institusi, dan melalui kemampuan individu menciptakan jaringan sosial (Fukuyama, 2001). Seymour (1992) menjelaskan bahwa etos kerja sangat berpengaruh besar pada kesuksesan Jepang dan negara-negara industri baru terutama kesuksesan dalam bidang ekonomi. Berdasarkan penjabaran sebelumnya hal ini menunjukkan bahwa terdapat hegemoni agama dan budaya yang mempengaruhi tingkah laku ekonomi suatu masyarakat dalam sebuah bangsa. Melalui metode studi pustaka, artikel ini akan mendeskripsikan keterkaitan tersebut.

\section{METODE PENELITIAN}

Penelitian ini adalah penelitian kualitatif yang mana dalam penelitian ini sumber-sumber dikumpulkan melalui studi kepustakaan, yaitu membaca, mengkaji, menela'ah, ataupun menganalisa literatur-literatur yang mengemukakan permasalahan yang dibahas, seperti korelasi perilaku ekonomi politi terhadap agama dan budaya. 
Data yang telah dikumpulkan dianalisa secara kualitatif, yaitu menguraikan dengan sejelasjelasnya tentang data yang berkaitan dengan masalah tingkah laku ekonomi-politik terhadap agama dan budaya. Sejauhmanakah politik ekonomi dalam mempengaruhi perilaku agama dan budaya setelah itu disimpulkan secara deduktif, yaitu menarik suatu kesimpulan dari pernyataanpernyataan yang bersifat umum ditarik ke khusus, sehingga hasil penelitian ini dapat dengan mudah dimengerti.

\section{HASIL DAN PEMBAHASAN}

\section{Etika Protestan dan Semangat Kapitalisme}

Beberapa penelitian tentang agama dan nilai-nilai tradisional dan budaya lokal memperlihatkan betapa kedua hal tersebut menjadi pendorong bagi kemunculan kapitalisme. Studi ilmiah mengenai hubungan antara agama dengan perkembangan ekonomi pertama kali diperkenalkan oleh Max Weber pada tahun 1905. Sebagai titik tolak analisisnya, Max Weber memakai hasil penelitian Martin Offenbacher (diterbitkan tahun 1901) mengenai perbedaan tingkah laku ekonomi masyarakat Katholik dan Protestan di Baden (Jerman). Menurut studi ini jelas kelihatan bahwa kaum Protestan lebih banyak mengirim anak-anak mereka ke sekolahsekolah menengah umum yang tidak mempunyai ikatan agama, daripada kaum Katholik. Di samping itu diketahui pula bahwa lebih banyak murid-murid yang beragama Protestan daripada Katholik yang mempelajari mata pelajaran-mata pelajaran yang cocok untuk menjadikan mereka teknisi dan wiraswasta masa depan (Weber, 1989).

Weber mencoba untuk mempelajari secara ilmiah hubungan antara agama (Protestan) dengan perkembangan ekonomi (kapitalisme). Tema pokok kerja Max Weber itu ialah bahwa pertumbuhan atau sosialisasi masing-masing anggota masyarakat yang berbeda-beda sesuai dengan pengaruh lingkungan mereka sendiri-sendiri menimbulkan sikap mental dan spiritual yang tidak sama dengan mereka yang tumbuh dan berkembang dalam lingkungan keluarga Katholik. Perbedaan ini akan banyak menentukan pemilihan lapangan pekerjaan/karier yang diinginkan dan diharapkan. Dengan lain perkataan, tingkah laku ekonomi mereka menjadi berbeda-beda.

Tulisan Weber dalam The Protestant Ethic and the Spirit of Capitalism menyebutkan peran yang dimainkan oleh agama, terutama etika yang menjiwai beberapa sekte Protestan tertentu, dalam perkembangan kapitalisme modern. Ini adalah kontribusi penting Weber dalam memahami sepenuhnya asal-usulnya kapitalisme modern. Dalam esainya Weber mencoba menjelaskan hakikat dan kemunculan suatu mentalitas baru, yang disebutnya semangat kapitalisme. Dia melihat semangat ini menggantikan tradisionalisme dalam kehidupan ekonomi. Selain itu, semangat kapitalisme, dalam pandangan Weber, merupakan aspek sentral dari kapitalisme modern.

Konsep 'semangat' - dalam hubungannya dengan semangat kapitalisme - itu didefinisikan sebagai suatu jenis tindakan sosial yang melibatkan pengejaran keuntungan maksimum dengan perhitungan rasional. Mentalitas seperti ini berkaitan dengan berbagai nilai seperti hemat, rajin dan asketisme dalam urusan-urusan ekonomi yang 'duniawi'. Dengan demikian, menurut Holton, semangat itu berlawanan dengan suatu semangat atau mentalitas lain yang disebut sebagai 
tradisionalisme ekonomi yang menjadi sifat pengejaran tujuan bukannya pengejaran keuntungan maksimum secara rasional (Abdullah, 1978).

Weber membedakan empat aliran utama Protestanisme asketik: Calvinisme, Baptisme, Metodisme dan Kesalehan (Pietism). Weber memusatkan analisisnya atas Etika Protestan pada Calvinisme. Pertama, doktrin bahwa semesta diciptakan untuk menunjukkan keagungan Tuhan yang Maha Besar, dan bahwa semua itu harus ditafsirkan sesuai dengan maksud dan kehendak Tuhan. Tuhan tidak ada demi keberadaan manusia, tetapi manusia ada berkat Tuhan. Kedua, asas bahwa maksud dan kehendak Tuhan tidak selalu bisa mengetahui sedikit kebenaran-kebenaran yang dikehendaki-Nya untuk dibukakan kepada manusia. Ketiga, kepercayaan kepada takdir: hanya sejumlah kecil manusia akan terpilih untuk diangkat ke surga (Sobary, 1995).

Weber menekankan, salah satu unsur fundamental dari semangat kapitalisme modern adalah tingkah laku rasional yang didasarkan pada gagasan mengenai 'panggilan'.Penekanan untuk kerja keras dan hidup hemat merupakan etika Protestan dalam sekte Calvinis (tidak untuk sekte lainnya seperti Luther atau Zwing Lie). Dua kata kunci itulah yang menjadi spirit kemunculan kapitalisme. Ajaran Kristen dipahami oleh sekte Calvin mengandung ajaran untuk selalu bekerja keras di dunia ini dan berlaku hemat atas apa yang telah didapat. Jadi, menurut Weber, agama merupakan pendorong kemunculan semangat kapitalisme.

Pengaruh teori dan analisis Max Weber telah banyak mempengaruhi ahli-ahli lain. Walaupun banyak pembaca Max Weber sering menemui kesulitan untuk dapat menerima teori dan analisisnya secara keseluruhan, dan oleh karena itu menjadi pengeritik-pengeritik yang tajam terhadapnya. Salah seorang di antaranya adalah ahli sejarah ekonomi Swedia, Kurt Samuelson. Menurut dia, di dalam bukunya Religion and Economic Action: A Critic of Max Weber (terjemahan dari bahasa Swedia, 1961), pada dasarnya baik Protestan maupun Katholik, bilamana berhubungan dengan masalah-masalah perekonomian, keduanya sebenarnya bertujuan tidak lain tidak bukan adalah membawahi dunia usaha dan perdagangan dengan norma moral Kristen yang keras dan ketat yang dengan sendirinya lebih memungkinkan untuk menghalangi atau menghambat dunia usaha dan perdagangan tersebut. Dengan lain perkataan, Kurt Samuelson berpendapat bahwa Etik Protestan atau unsur agama boleh dikatakan tidak mempunyai hubungan apa-apa dengan proses perkembangan ekonomi dunia Barat dari dulu sampai sekarang. Perkembangan tersebut dilihatnya sebagai akibat langsung dari mercantilisme, the enlightment, darwinisme dan liberalisme ekonomi yang semuanya bukanlah barang pinjaman dari protestanisme maupun dari puritanisme, melainkan elemen-elemen tersendiri yang terpisah dari kepercayaan agama (Alfian, 1986).

Ditinjau dari segi lain, teori Max Weber sering pula dikritik orang karena di beberapa tempat di mana agama Protestan tidak ada atau tidak berkembang, masyarakatnya toh masih bisa maju. Demikianlah umpamanya kenyataan yang dialami Jepang dalam proses perkembangan ekonominya baik sebelum maupun sesudah Perang Dunia II. Menurut pendapat beberapa ahli, unsur-unsur "kerja keras" dan "hemat" yang sering dikaitkan dengan Etik Protestan itu juga merupakan sifat yang dihayati oleh bangsa Jepang. Kalau memang demikian halnya, apa yang disebut sebagai unsur-unsur etik Protestan tidak hanya terbatas di dalam agama itu saja. Mereka 
mungkin saja bisa ditemui, seperti di Jepang, di dalam agama-agama atau kebudayaan-kebudayaan lain di dunia ini. Sejalan dengan ini suatu penelitian yang sungguh-sungguh dan cermat mengenai pengaruh beberapa agama lain seperti Hindu-Buddha dan Islam terhadap tingkah laku ekonomi dan penganut-penganutnya mungkin bisa mendapat tempat yang layak dari ahli-ahli sosiologi agama.

Tradisi dalam konsepsi sosiologi adalah upaya cerdas saat itu yang dicapai dan dilakukan oleh masyarakat secara berulang-ulang dan dapat dilihat sebagai pengetahuan yang diwarisi secara turun temurun, yang didukung oleh mekanisme sanksi. Aneka tradisi yang dipandang sebagai penghalang bagi pembangunan ekonomi harus dilihat sebagai tantangan untuk memberikan jalan terhadap kekuatan pasar dan standarisasi proses dan hasil industri. Standarisasi aneka proses dan produksi ekonomi adalah batu loncatan kepada masa depan yang memprasaranai kemajuan (Aspers, 1999).

Di Jepang, agama Tokugawa dan nilai-nilai tradisional memberikan kontribusi terhadap akselerasi pembangunan ekonomi di sana. Proses industrialisasi di Jepang pertama kali digerakkan bukan oleh kelas pedagang ataupun industriawan, melainkan oleh kaum samurai. Terdapat suatu etika dalam tradisi samurai yang memungkinkan nilai-nilai tradisional tersebut dapat beradaptasi dan dapat pula dijadikan modal utama dalam proses industrialisasi. Etika samurai menekankan pengoperasian semua bentuk usaha dengan memegang teguh janji demi negara, dan memberikan spirit untuk bekerja keras dan tangguh dengan tetap memperhatikan kepentingan dan rasa orang lain (Bellah, 1992).

\section{Etika Konfusius dan Keberhasilan Bisnis Tionghoa}

Awal mula pembangunan ekonomi yang berlandaskan kapitalisme terjadi di negara-negara Barat yang lebih menggunakan praktek-praktek bisnis yang lebih mengarah kepada kepentingan individual untuk memperoleh kekayaan (Brook dan Luong, 1999). Sebaliknya, ideologi kapitalisme tidak serta-merta mempengaruhi pokok-pokok pembangunan ekonomi di negaranegara Timur. Weber (1951) berpendapat bahwa budaya Konfusianisme yang menekankan prinsipprinsip hubungan kekeluargaan antar sesama manusia telah menghambat perkembangan kapitalisme di negara-negara Timur yang kental dengan budaya Konfusius. Namun, keberhasilan bisnis orang Cina perantauan di banyak bagian Asia Tenggara seringkali dinyatakan untuk mendukung tuntutan-tuntutan seperti halnya catatan-catatan kinerja negeri-negeri Asia Timur lain dengan warisan budaya Konfusius atau neo-Konfusius yang lain. Namun, hipotesis nilai-nilai Konfusius, yang kadang-kadang dinyatakan untuk menjelaskan tingkat pertumbuhan dan dinamisme ekonomi, dapat diterima hanya dengan kualifikasi yang kuat (Hefner, 2000).

Karena keanekaragaman Cina perantauan dan berbagai keadaan lingkungan regional yang mereka hadapi, banyak variabel penjelasan yang relevan dengan explicandum di sini - faktor-faktor sosial dan budaya maupun kelembagaan dan struktural. Bahkan hanya sedikit orang Cina yang mengabaikan dugaan keberuntungan atau nasib baik (banyak di antara merekapenjudi besar), karena hal itu berakar dalam kebudayaan Cina, geomancy, dan numerologi. Jelas, nilai-nilai dan 
budaya adalah faktor-faktor penting dalam semua ini - atau, lebih tepat, nilai-nilai dalam konteks sosio-politik mereka - tetapi unsur-unsur struktural dan kelembagaan dalam kehidupan ekonomi Asia juga krusial.

Penelitian oleh Tu (1989) menemukan keseragaman konsep etika dasar dan sistem nilai pada negara-negara China, Jepang, Korea, dan negara industri baru lainnya. Masyarakat etnis Tionghoa terutama di negara China dan Empat Macan Asia (Korea Selatan, Taiwan, Hongkong, dan Singapura), termasuk Indonesia, memiliki kesamaan karakteristik dalam berbisnis. Dalam menjalankan bisnis, masyarakat etnis Tionghoa selalu berpegang pada etos kerja disiplin, pekerja keras, hemat, jujur dan konsisten dalam pelaksanaan tugasnya. Apabila dikaji, etos-etos kerja ini berakar dari ajaran Konfusius yang telah menjadi budaya etnis Tionghoa. Tipikal budaya Tionghoa tercermin dalam etos kerja pekerja-pekerja di negara-negara industri baru. Menurut penelitian yang dilakukan oleh Jaw, et.al (2007) terhadap para pekerja Tionghoa, terdapat pengaruh antara nilainilai budaya Tionghoa dengan nilai-nilai yang dianut pada saat melakukan pekerjaan. Pada umumnya, etnis Tionghoa memiliki etos kerja yang sangat disiplin, mau bekerja keras dalam situasi yang berat, hemat, jujur, konsisten dalam pelaksanaan tugasnya. Tipikal kerja yang demikian tidak terlepas dari nilai-nilai Konfusius yang telah ditanamkan dalam keluarga sejak kecil (Kuncono, 2012).

Sistem manajemen perusahaan etnis Tionghoa juga tidak terlepas dari nilai-nilai budaya Tionghoa. Nilai-nilai budaya Tionghoa dipandang memiliki peranan penting dalam menentukan jalannya sebuah organisasi bisnis dan praktek manajerial perusahaan-perusahaan Tionghoa (Sheh, 2001). Bagi etnis Tionghoa, perusahaan bisnis merupakan sebuah entitas ekonomi dimana caracara menjalankan perusahaan tersebut amat dipengaruhi oleh nilai-nilai Konfusius. Nilai-nilai Konfusius telah berkembang menjadi bagian yang tidak dapat terpisahkan dari budaya Tionghoa (Mely G Tan, 1996). Konfusianisme merupakan sistem etika dan filosofi yang diajarkan oleh Konfusius, seorang filsuf sekaligus agamawan dari China. Pada hakekatnya, ajaran Konfusius merupakan sebuah sistem yang mengajarkan tentang moral, sosial kemasyarakatan, aspek politis, dan filosofis yang menitikberatkan pada kepentingan komunitas dibandingkan kepentingan individu (Tu, 1989). Konfusianisme berkaitan dengan moral dan aturan yang mencakup bagaimana seharusnya seorang individu berinteraksi terhadap Tuhan dan sesamanya, baik dalam lingkungan kecil yakni tingkat keluarga, berinteraksi pada masyarakat (pada tatanan organisasi), dan meluas ke interaksi dalam bernegara (tatanan pemerintahan) bahkan interaksi dalam kerjasama internasional (dalam hubungan dengan antar Negara) (Kuncono, 2012).

Budaya Konfusius juga menanamkan sikap dan perilaku untuk bekerja keras, hemat, suka menabung, tidak putus asa dan menjaga nama baik melaui kepercayaan telah mengakar pada tradisis Tionghoa. Mengakarnya ajaran Konfusius dalam setiap aspek kehidupan masyarakat Tionghoa, telah menjadikan ajaran Konfusius sebagai bagian yang tidak terpisahkan dari budaya Tionghoa (Indarto). Hal inilah yang menyebabkan setiap membicarakan budaya Tionghoa tidak bisa begitu saja melepaskan tentang Konfusius dan begitu pula sebalikknya setiap berbicara Konfusius selalu berkaitan dengan budaya Tionghoa. Budaya Tionghoa yang diwakili Etika 
Konfusius bukan saja membudaya, melainkan telah menjadikan perilaku nyata dalam kehidupan sehari-hari bahkan telah berpengaruh positif terhadap tingkah laku bisnis orang orang Tionghoa. Seperti yang dikatakan Tan bahwa nilai-nilai loyalitas terhadap keluarga yang diajarkan Konfusius ini diyakini menjadi latar belakang kesuksesan pembangunan ekonomi Singapura (Tan, 1989).

Disamping Konfusius adalah suatu ajaran filsafat dan etika moral juga sebagai suatu agama yang didalamnya terdapat ritual yang harus dilakukan oleh pengikutnya (Adi Nugroho: 13). Secara agama atau kepercayaan dan etika moral, ajaran Konfusius akan mendorong pengikutnya untuk mencapai kesejahteraan, kemakmuran, dan kebahagiaan hidup secara harmonis melalui persembahan pada leluhur dan Tian. Sebagai agama, Konfusius mengajarkan suatu kepercayaan dan keyakinan pada pengikutnya bahwa seorang yang bajik itu pasti mendapat berkah: rejeki dan kesuksesan seperti yang dikatakan Konfusius " Maka seorang yang berkebajikan besar niscaya mendapat berkah, kedudukan, nama dan panjang umur". Kepada yang berbuat baik akan diturunkan beratus berkah, kepada yang berbuat tidak baik akan diturunkan beratus kesengsaraan. Keyakinan akan perbuatan kebajikan oleh orang Tionghoa yang pada akhirnya membawa berkat, rejeki, kesuksesan dan panjang umur itulah yang menyebabkan orang Tionghoa bekerja keras berdasarkan pada nilai nilai kebajikan. Bagi orang Tionghoa hanya berbisnis dengan bajik itulah Tuhan akan meridhoinya. Hal ini sesuai dengan ajaran Konfusius yang mengatakan "Wi Ti Thong Thian" (Hanya dengan Kebajikkan saja Tuhan akan berkenan).

Ajaran Konfusius diatas dalam kontek rasional sebenarnya menjelaskan kepada kita tentang hubungan antara etika dengan kesuksesan seperti halnya tesis Max Weber yang sebenarnya membahas antara hubungan motif dengan tindakan. Ajaran tersebut diatas menjadikan orang Tionghoa tidak berani tidak berbuat Kebajikan karena diyakini akan menjadikan kemakmuran dan kesuksesan dalam hidupnya, sebalikknya mereka akan takut berbuat yang menentang etika moral (tidak bajik) dikarenakan takut akan kesengsaraan. Untuk itulah orang orang Tionghoa berusaha bekerja keras sesuai dengan jalan Tuhan (kebajikan) untuk mencapai kesuksesan yang benar.

Khususnya Indonesia banyak pengusaha sukses dari kalangan Etnik Tionghoa yang kalau dikaji ternyata memiliki kesamaan ciri dengan Etnis Tionghoa di beberapa Negara seperti Singapore, Malaysia, Taiwan dan Hongkong. Kesamaan karakteristiknya adalah bahwa Etnis Tionghoa dalam berbisnis secara kekeluargaan, xuangxi, dan prinsip prinsip kepercayaan. Kesamaan tersebut kalau ditarik ternyata berkaitan dengan ajaran Konfusius (Hefner, 2000).

Seperti telah kita ketahui bahwa sekarang ini hampir $80 \%$ pengusaha yang sukses berasal dari kalangan Tionghoa (Usman, 2009). Hal itu dikarenakan kemampuan dan kinerja mereka yang ulet dan tangguh. Prinsip orang Tionghoa, "Apa yang kami lakukan hari ini, bukan untuk hari ini saja, tapi untuk kedepan" Jadi kedepan untuk apa? Sehingga perlu modal, modal bukan hanya uang saja, tapi bisa juga keterampilan, semangat dan kepercayaan sehingga harus pandai bergaul serta berkomunikasi dan hubungan atau koneksi (quanxi). Perdagangan adalah lahan satu-satunya yang paling memungkinkan untuk saling berkomunikasi dan bergaul, saling kenal dan membangun relasi. Begitu juga menjadi pedagang bukan karena faktor keturunan. Ini lebih berkaitan dengan 
pendidikan awal di lingkungan keluarga sebagai akar budaya khas, dengan alasan keluarga Tionghoa tidak semudah suku lain sehingga mereka bekerja keras.

Selain itu ajaran-ajaran Konfusius juga sangat berpengaruh dalam kehidupan bisnis yang mereka jalankan, karena mereka berpegang teguh pada ajaran-ajaran Konfusius di antaranya : perubahan (Yin Yang), kepercayaan (Xin), cinta kasih (Ren), kebenaran (Yi),kebijaksanan (Zhi), keberanian (Yong), kesusilaan (Li), dan jaringan/hubungan (Xuansi) (Hefner, 2000).

Kedelapan ajaran tersebut sangat berguna untuk menjalankan usaha bisnis mereka, karena antara faktor yang satu dengan faktor yang lainnya saling berkaitan. Oleh sebab itu dalam kajian ini, penulis akan mencoba membahas kaitan nilai nilai Konfusius diatas terhadap kesuksesan bisnis etnik Tionghoa.

\section{Etika Islam dan Motivasi Ekonomi Pribumi}

Beberapa ahli ilmu sosial yang mempelajari masyarakat-masyarakat Islam atau negaranegara yang mempunyai sejumlah besar penduduk beragama Islam paling kurang mencoba secara garis besarnya menunjukkan hal-hal tertentu dari pengaruh kepercayaan bawaan Nabi Muhammad ini terhadap tingkah laku ekonomi penganut-penganutnya. Di Indonesia, Islam sering pula dihubungkan dengan kaum pedagang dan pengusaha. Kedatangan dan proses perkembangan agama ini di sini diperkirakan banyak tergantung pada kegiatan pedagang-pedagang Islam. Mulanya mereka menguasai kota-kota pantai dan daerah pesisir dari Nusantara ini dari mana mereka menyusup ke dalam untuk berusaha mengislamkan mereka yang tinggal di pedalaman.

Menurut Clifford Geertz dalam masyarakat Jawa perbedaan nilai kepercayaan banyak mempengaruhi tingkah laku kehidupan sosial mereka yang lambat laun menjurus kepada tiga pola tertentu, yaitu santri, abangan dan priyayi. Kaum santri berhasil menjadi pemilik-pemilik tanah dan sawah yang relatif luas di pedesaan, dan oleh karena itu menurut ukuran setempat sebagian dari mereka termasuk orang-orang yang relatif berada atau kaya. Di lain pihak, mereka yang tergolong ke dalam kaum abangan banyak yang tidak mempunyai tanah atau sawah, dan karena itu kehidupan mereka banyak tergantung pada pemilik-pemilik tanah/sawah yang luas sebagai apa yang lazim disebut "buruh tani". Kontras sosial ekonomi yang jelas ini sering menjurus pada tingkah laku politik yang radikal yang mengakibatkan pertentangan tajam antara santri dan abangan (Alfian, 1986).

Di samping itu, sungguh pun mungkin benar bahwa sebagian santri petani di Indonesia berusaha berhemat dan mengumpulkan uang, sering hal semacam itu dilakukan karena keinginan dan hasrat untuk menunaikan Rukun Islam kelima, naik haji ke Mekkah, bukanlah buat mengumpulkan kapital guna mengembangkan bidang usaha mereka. Bakan ada beberapa kasus yang menunjukkan bahwa untuk keperluan pergi naik haji tersebut beberapa orang dari mereka sampai berani menjual sebagian besar harta benda mereka - termasuk tanah dan sawah - tanpa mengingat kepentingan perekonomian mereka yang mungkin akan sangat sukar sekembali dari tanah suci nanti. 
Hal ini cederung lebih menunjukkan bahwa kalaulah memang ada unsur-unsur agama (Etik Islam atau Etik Santri) yang mendorong para santri petani di pedesaan untuk berhemat dan bekerja keras, kelihatannya hal itu lebih banyak disebabkan oleh keinginan untuk memenuhi kewajiban agama, terutama pergi naik haji ke Mekkah, daripada oleh keinginan untuk meningkatkan atau mengembangkan bidang usaha ke jurusan lain yang mungkin jauh lebih menguntungkan. Dalam hal ini dan ditinjau semata-mata dari segi ekonomi, mungkkin dapat dimengeri kalau ada sejumlah ahli yang mngeritik bahwa sering pada prakteknya tingkah laku ekonomi sebagian santri petani kelihatannya kurang rasional. Sebagaimana yang diketahui bahwa rasionalisme merupakan salah satu unsur penting dalam proses pembangunan ekonomi.

Karakteristik masyarakat pedesaan yang berbeda dengan karakteeristik masyarakat perkotaan, ternyata ketika dihubungkan antara tingkah laku ekonominya dengan agama, pada kenyataan orientasi mereka sama. Pembangunan ekonomi ketika era Orde Baru telah berhasil membangun kembali perekonomia Indonesia yang telah rusak sejak akhir tahun 1960-an. Pemerintah Orde Baru menjadikan pembangunan ekonomi sebagai prioritas utama bersamaan dengan kebijakan industrialisasi. Kebijakan ini selanjutnya menuntut perluasan kota sebagai kebutuhan yang mendesak. Jakarta sebagai pusat industri terbesar di Indonesia memberikan pengaruh terhadap kota-kota dan desa-desa disekitarnya. Sebagai akibatnya, komunitas-komunitas desa mulai mengalami perubahan radikal yang berjangka panjang. Perubahan ini termasuk nilainilai sosial, ikatan-ikatan antar pribadi, pola-pola tata guna lahan, pola-pola kegiatan pencarianpenghasilan dan orientasi sosio-politiknya. Ringkasnya, pembangunan menyebabkan runtuhnya bentuk struktur sosial desa yang tradisional. Dengan demikian maka biaya sosial dari pembangunan tampaknya terlalu mahal. Penduduk desa ditarik sumbangan yang terlalu besar untuk pembangunan, tetapi menerima manfaat terlalu kecil karena strategi pembangunan diarahkan lebih banyak kepada kota ketimbang daerah-daerah pedalaman (Sobary, 1995).

Hal ini merupakan gambaran yang relevan mengenai pola hubungan antara Jakarta di satu sisi dengan desa-desa pinggiran, seperti perkampungan Betawi, di sisi lain. Komunitas Betawi, sebagai bagian dari pinggiran sejak lama telah dihadapkan kepada perluasan daerah-daerah industrial yang diuntungkan oleh proses modernisasi dan perluasan kota. Tekanan-tekanan demografik dan geografik ibu kota, dan kebijakan-kebiakan pemerintah untuk merangsang industrialisasi, memiliki implikasi-implikasi serius bagi komunitas Betawi. Ketika terjadi ledakan populasi di Jakarta, gelombang imigrasi penduduk telah menjadikan orang Betawi sebagai minoritas yang terancam, yang terdesak dari kampung-kampung mereka oleh pertumbuhan kota. Ketika Jakarta menjadi pusat kehidupan kota modern, kebudayaan Betawi disisihkan karena dianggap tidak relevan lagi. Orang Betawi dengan demikian terus-menerus harus mengalami proses penyesuaian dengan situasi-situasi yang terus berubah sehingga mereka semakin termarjinalisasi. Mereka telah terlempar dari lahan-lahan mereka yang berubah menjadi pemukiman-pemukiman baru, jalan raya, blok-blok perkantoran dan pusat perbelanjaan serta hotelhotel (Sobary, 1995). 
Dalam keadaan seperti ini, orang Betawi sangat erat dengan agama (Islam), dan memakainya sebagai dasar identitas diri karena Islam memberi perasaan bangga dan perlindungan psikologis dari perasaan terancam. Pada waktu yang sama kecerdasan bisnis mereka memberi jawaban terhadap masalah-masalah ekonomi yang mereka temui sehari-hari. Dengan demikian agama dan bakat bisnis kecil-kecilan telah dipakai sebagai sarana kelangsungan hidup bagi penduduk yang terdiskriminasi dari wilayah industrialisasi. Karena itu bisa dimengerti bahwa ketika mereka bergiat dalam bisnis, mereka terlihat tahan uji. Selain itu, mereka juga memiliki semangat komersialisme: hemat, kerja keras, rajin, terampil dan mengaitkan kegiatan-kegiatan keagamaan tertentu dengan upaya komersial. Pernyataan yang terakhir ini dengan pengertian bahwa di belakang kegiatan keagamaan mereka biasanya bisa ditemukan motivasi-motivasi komersial. Gagasan yang menempatkan ushali dan usaha dalam kedudukan seimbang menunjukkan, di satu sisi, bagaimana seriusnya mereka melakukan kegiatan komersial, dan di sisi lain, jelas terdapat kaitan antara ideologi atau ajaran agama (idealisme) dengan tingkah laku ekonomi (tindakan sosial konkret).

Sebagaimana yang terlihat dalam simbol-simbol keagamaan seperti: pergi haji, berziarah, slametan, semuanya itu memiliki motivasi ekonomi yang kuat bagi masyarakat. Menunaikan ibadah haji misalnya bukan hanya dimotivasi oleh keinginan untuk memperoleh prestis moral, tetapi juga karena adanya keuntungan-keuntungan sosio-ekonomi yang dinikmati para haji ini, yaitu dalam berdagang, para haji lebih mendapatkan kepercayaan dari pembeli. Namun, pengaruh agama tidak secara langsung membentuk tingkah laku ekonomi masyarakat tetapi melalui budaya lebih dahulu. Karena itu dari permukaan kita hanya melihat kaitan duniawi atas semangat komersial mereka; yaitu mereka bekerja hanya untuk mencari tambahan penghasilan buat kehidupan keluarga. Jadi tanpa analisis yang peka dan cermat kita tidak bisa mengungkap adanya keberartian keagamaan dalam kehidupan komersial masyarakat. Pendeknya, agama Islam, memainkan peran yang menentukan dalam membentuk semangat berdagang di kalangan masyarakat Indonesia. Agama sering dipakai guna membenarkan apa yang telah mereka capai secara ekonomi, karena mereka tidak mau dianggap berbuat sesuatu yang berentangan dengan aaran-ajaran Islam. Jelasnya, agama rupanya lebih kurang dipakai sebagai faktor pendorong, kalaulah ada, untuk berbuat sesuatu (bekerja keras dan berhemat), tetapi lebih banyak dipergunakan untuk membenarkan (menghalalkan) sesuatu yang telah diperbuat (Sobary, 1995).

Jika teori Weber direlevansikan dengan kenyataan tingkah laku ekonomi kaum Protestan di Indonesia, teori tesebut akan mengundang banyak pertanyaan. Jika diperhatikan tingkah laku ekonomi suku Batak yang beragama Protestan mungkin sedikit banyaknya unsur kebenaran dari analisis Max Weber tersebut. Tetapi, jika hal tersebut difokuskan kepada suku-suku Ambon dan Manado yang juga beragama Protestan maka hal ini akan sulit untuk diketahui relevansi analaisis Weber tersebut. Berbeda dengan orang-orang Batak Protestan, orang-orang Manado dan Ambon Protestan kelihatannya jauh kurang berhasil dalam dunia usaha dan dagang, terutama dalam berkompetisi dengan suku-suku atau golongan ras lain seperti Minangkabau, Bugis, Tionghoa dan Arab. 
Kenyataan ini menimbulkan pertanyaan apakah tidak mungkin keberlainan tingkah laku ekonomi antara pemeluk-pemeluk agama Protestan dari berbagai suku tersebut disebabkan oleh faktor-faktor lain seperti pengaruh adat-istiadat masing-masing daerah, pengaruh alam yang berlainan, perbedaan dalam corak struktur kekuasaan setempat, hadir atau tidak hadirnya saingansaingan berat dari suku-suku atau golongan ras lainnya? Ataukah mungkin pula disebabkan oleh adanya perbedaan yang jelas dalam ketaatan anggota masing-masing suku terhadap agama mereka - mapakah orang-orang Batak mungkin lebih taat dari orang-orang Ambon dan Manado - ataukah sebaliknya? Ataukah memang agama Protestan tidak mempunyai pengaruh apa-apa sama sekali terhadap tingkah laku ekonomi penganutnya?

Geertz melakukan pengujian atas keberlakuan tesis Weber. Geertz mengambil masyarakat yang sadar akan kesatuan kulturalnya, di samping menyadari adanya perbedaan (variant) dalam penghayatan agama, seperti di "Mojokuto", atau status seperti di Tabanan. Santri di "Mojokuto" dan kaum bangsawan di Tabanan bukanlah kelompok sosial yang asing, baik dari sudut etnis atau pun dari sudut geografis, tetapi secara struktural adalah bagian dari masyarakat sekitarnya. Jika pada kasus Tabanan, kegiatan ekonomi dari kaum bangsawan dapat dilihat sebagai dorongan dari status sosialnya, maka pada kasus kaum santri Geertz melihat suatu paralelisme dengan berfungsinya "etika Protestan". Baik kaum bangsawan di Tabanan dan santri di Mojokuto sedang mengalami reformasi. Terutama hal ini tampak pada kalangan santri, yang telah sejak beberapa waktu mulai mempersoalkan validitas atau keberlakuan dari praktek dan penghayatan keagamaan mereka. Secara "etika", dalam pengertian Weber, Geertz melihat adanya unsur "semangat kapitalisme" dalam arti tekun, hemat dan beperhitungan. Tetapi "semangat" ini tidak didukung oleh kemampuan organisasi yang baik. Jadi dengan kata lain ia neranggapan bahwa ketidaksamaan golongan santri, yang reformis, terletak pula pada ketiadaan dukungan struktural. Dalam hal ini ia memang setuju tampaknya dengan Weber bahwa adanya "afinitas yang saling mencari" merupakan persyaratan yang utama pula (Abdullah, 34).

Siegel memang lebih memperhatikan sikap pribadi dalam kegiatan ekonomi, sedangkan Geertz mencoba menangkap siatuasi rohaniah yang mewarnai kegiatan ekonomi dan kemudian mencoba menghubungkannya dengan kegiatan ekonomi. Keduanya melihat kelemahan organisasi sebagai penghalang utama bagi peningkatan kemampuan ekonomi dari santri Jawa dan pedagang Aceh. Pengetahuan akan hal ini pulalah antara lain yang menyebabkan Wertheim menyangsikan kemampuan santri untuk bisa meningkatkan dirinya lebih dari pedagang bazaar saja. Tanpa mempersoalkan kemungkinan adanya hubungan antara keyakinan agama dengan perilaku ekonomi, yang bersifat psikologis itu, Wertheim menyangsikan sumbangan dan kemampuan perseorangan dalam perkembangan ekonomi. Bukan orientasi pribadi, tetapi perkembangan ekonomilah yang jadi perhatiannya. Jadi Wertheim lebih tertarik pada suasana ekonomi umum daripada etos kerja. Ia beranggapan bahwa perkembangan ekonomi suatu negara lebih ditentukan oleh sikap dari birokrasi. Dari sudut lain dapat dikatakan bahwa Wertheim sesungguhnya membenarkan Weber bahwa pada akhirnya birokrasi akan mengungguli kapitalisme (Abdullah, 2010). 
Jika teori Weber direlevansikan dengan tingkah laku ekonomi masyarakat muslim di Indonesia, ada suatu kegagalan dalam mengembangkan perekonomian Indonesia. Pertama, masyarakat Indonesia dihadapkan pada keterbatasan-keterbatasan pemasaran yang berat. Kedua, meskipun masyarakat memiliki bakat, kegigihan, pengalaman lama dan luas serta semangat berdagang, namun mereka beroperasi secara perorangan sehingga mereka tidak dapat membentuk organisasi komersial. Ketiga, semangat dan etos kerja masyarakat Indonesia hampir sama dengan etos Protestan di Barat, hanya saja semua pengaruh keagamaan diserap lebih dahulu ke dalam kebudayaan masyarakat. Sehingga pengaruh agama tidak secara langsung membentuk tingkah laku ekonomi tetapi melalui kebudayaan lebih dahulu. Keempat, - alasan non-struktural - masyarakat tidak memiliki cukup modal (Sobary, 1995).

\section{KESIMPULAN}

Ajaran-ajaran agama yang membatasi ruang gerak atau tingkah laku ekonomi para santri, seperti masalah "riba" atau pembangunan uang diperkirakan turut mempengaruhi. Selanjutnya, sebagaimana telah kita lihat di kalangan pemeluk agama Protestan di Indonesia, tingkah laku ekonomi muslim Minangkabau kelihatan berbeda dengan muslim Sunda, Madura, Lampung, atau Betawi, sebagaimana dapat dilihat dari berhasil atau tidaknya mereka di dunia usaha dan dagang. Dalam hal ini pertanyaan yang sama yang dapat diajukan, yaitu apakah perbedaan ketaatan, pengaruh alam yang berbeda, perbedaan dalam struktur dan kebijaksanaan penguasa setempat, perbedaan tingkat pendidikan dan sebagainya - sistem nilai-nilai yang berlaku - telah menimbulkan perbedaan-perbedaan semacam itu? Dengan kata lain, agama dengan etiknya mungkin bukanlah suatu faktor penentu, tetapi merupakan faktor yang memperkuat sistem nilai tersebut sehingga lebih tepat dianggap sebagai intervening variable.

Tampaknya etika tiap-tiap agama mengenai kerja keras, hemat, dan manifestasi ekonomi dari kehidupan perdagangan sangat bervariasi. Meski demikian, ada satu cacatan yang dapat ditarik sebagai suatu kesimpulan, yaitu letak perbedaan signifikannya adalah kegagalan masyarakat Indonesia membentuk korporasi besar, dan mereka hanya puas menjadi pengusaha kecil. Sementara spirit Protestan di Barat dan Konfusius Tionghoa menjadi ideologi besar yang melahirkan pengusaha kelas elite yang bahkan menguasi struktur ekonomi dunia.

Mengapa itu terjadi? Pertama, mereka dihadapkan keterbatasan-keterbatasan pemasaran yang berat. "Pasar" tempat mereka beroperasi sangat sempit, sedangkan daya dukung penduduk sangat rendah. Sekuat apapun semangat keagamaan, mereka berkutat dalam ruang lingkup yang sempit. Kedua, mereka memiliki bakat, kegigihan, pengalaman lama, serta semangat berdagang. Sayang, mereka beroperasi secara perorangan, sehingga gagal mencipta korporasi sosial yang melibatkan puluhan atau ratusan pengusaha dalam menentukan arah perekonomian. Ketiga, spirit keagamaan masyarakat Indonesia tidak sekuat sebagai "panggilan" kaum calvinis Protestan. Berdagang hanya untuk memenuhi kebutuhan keluarga, bukan sebuah panggilan suci yang menjadikan mereka bangga sebagai "terpilih". Keempat, mereka tidak mempunyai cukup modal 
dan belum mempunyai kontruksi pemahaman dalam mengembangkan modal, sekalipun mereka diberi kredit modal.

Menurut Arthur Lewis agama bisa menjadi penghalang atau sebaliknya pendorong perkembangan ekonomi, tergantung pada pengaruhnya terhadap hal-hal ekonomi seperti penekanan pada nilai materiil, kerja, kehematan, penanaman modal secara menguntungkan dan sebagainya. Dalam suasana pembangunan seperti sekarang ini, buah pikiran semacam itu rupanya perlu diteruskan kepada ahli-ahli dan pemuka-pemuka agama, baik Islam, Protestan, Katholik, Konghuchu maupun yang lainnya agar supaya mereka dapat menentukan pilihan mereka dan dengan itu membimbing massa mereka masing-masing. 


\section{DAFTAR PUSTAKA}

Abdullah, Taufik. (1978). Agama, Etos Kerja dan Perkembangan Ekonomi. Jakarta: Yayasan Obor Alfian. (1986). Transformasi Sosial Budaya Dalam Pembangunan Nasional. Jakarta: UI-Press

Aspers, Patrick. (1999). The Economic Sociology of Alfred Marshall: An Overview, American Journal of Economics and Sociology

Bellah, Robert. N. (1992). Religi Tokugawa; Akar-akar Budaya Jepang, Jakarta:Gramedia Pustaka Utama

Chalid. (2005). Sosiologi Ekonomi. Jakarta: CSES Press

Heffner, Robert W. (2000). Budaya Pasar, Jakarta: LP3ES.

Narwoko, J. Dwi dan Suyanto, Bagong. (2011). Sosiologi Teks Pengantar dan Terapan. Jakarta: Kencana

Sobary, Mohammad. (1995). Kesalehan dan Tingkah Laku Ekonomi. Yogyakarta: Yayasan Bentang Budaya

Weber, Max. (1989). The Protestant Ethic and The Spirit of Capitalism, Unwin Hyman. London 